\title{
Monitoring the ecological state of a hypertrophic lake (Albufera of València, Spain) using multitemporal Sentinel-2 images
}

\author{
Xavier Sòria-Perpinyà ${ }^{1, *}$, Patricia Urrego ${ }^{2}$, Marcela Pereira-Sandoval², Antonio Ruiz-Verdú2, \\ Ramón Peña ${ }^{2}$, Juan M. Soria ${ }^{1}$, Jesús Delegido ${ }^{2}$, Eduardo Vicente ${ }^{1}$ and José Moreno ${ }^{2}$ \\ ${ }^{1}$ Image Processing Laboratory, Universitat de València. C/ Catedrático José Beltrán Martínez, 2. 46980, \\ Paterna, València. \\ ${ }^{2}$ Cavanilles Institute of Biodiversity and Evolutionary Biology (ICBiBE). Universitat de València. C/ Catedráti- \\ co José Beltrán Martínez, 2. 46980, Paterna, València. \\ * Corresponding author: Javier.Soria-Perpina@uv.es
}

Received: 15/02/18 Accepted: 26/09/18

\begin{abstract}
Monitoring the ecological state of a hypertrophic lake (Albufera of València, Spain) using multitemporal Sentinel-2 images

Albufera of València, a hypertrophic lake, has been studied extensively since the 1980s, but the efforts to revert the system to a clear water state have not yielded the expected results because pressure on this system is growing (increase in nutrient-rich water inputs, decrease in precipitation and increase in evaporation). The current state of the lake requires constant monitoring, and one of the main biological parameters used in ecology and water management to monitor and control the ecological status of aquatic ecosystems is chlorophyll $a$ concentration [Chl- $a$ ]. In this sense, remote sensing is an optimal tool for continuous monitoring of the quality state of the water body through [Chl-a] and to obtain a better understanding of its spatial dynamics. This work aims to demonstrate the validity of an algorithm for [Chl- $a$ ] retrieval from Sentinel-2 (A and B), the new Earth observation satellites of the European Space Agency, with the sensor MSI, multispectral (13 bands) from $404 \mathrm{~nm}$ to $2200 \mathrm{~nm}$, a spatial resolution of $10 \mathrm{~m}$ and a temporal frequency of 5 days - values unthinkable until now as regards to open access images. The study was carried out with images from 2016 and 2017, but only 40 images out of the 81 taken by the satellite could be used - such rate was mainly due to unfavourable weather conditions. Once images were downloaded, the SNAP 5 software was used for the processing. Using the Sen2cor tool, they were corrected atmospherically and, with the algorithm developed by Soria et al. 2017, lake [Chl-a] was estimated. Estimated data were validated against field samples: a total of 18 sampling campaigns were carried out and 92 samples were taken to measure the [Chl- $a$ ]. In addition, to better interpret results, data on conductivity and Secchi disk depths measurements were taken in the field and hydrological, precipitation and wind data were also collected. Results of the validation were deemed very good since an $\mathrm{R}=0.8$ was obtained when applying a linear correlation between field data and estimates, which shows the robustness of the algorithm used. From the interpretation of the thematic maps, it was possible to infer that the temporal evolution in [Chl-a] variations follows an annual bimodal pattern, where the decrease in $[\mathrm{Chl}-a]$ is determined either by a significant increase in water renewal of the lake or by the depletion of the available nutrients in the water due to a previous excessive growth of phytoplankton.
\end{abstract}

Key words: eutrophication, water quality, water management, chlorophyll- $a$, remote sensing

\section{RESUMEN}

Seguimiento del estado ecológico de un lago hipertrófico (Albufera de València, Spain) usando imágenes multitemporales de Sentinel-2

El lago de la Albufera de València, un lago hipertrófico, ha sido largamente estudiado desde los años 80, pero los esfuerzos en revertir el sistema a un estado de aguas claras no han dado los frutos esperados debido a que la presión sobre este sistema es cada vez mayor (aumento de aguas ricas en nutrientes, disminución de la precipitación y aumento de la evaporación). El 
estado en que se encuentra el lago requiere un seguimiento constante, y uno de los principales parámetros biológicos utilizados en ecología y gestión del agua para el seguimiento y control del estado ecológico de los ecosistemas acuáticos es la concentración de clorofila a [Chl-a]. En este sentido, la teledetección es una óptima herramienta para el seguimiento continuo del estado de calidad de la masa de agua a través de la [Chl-a], permitiendo además, entender mejor su dinámica espacial. En este trabajo se pretende demostrar la validez de un algoritmo para la estimación de [Chl-a] a partir de imágenes de Sentinel-2 ( A y B), los nuevos satélites de observación de la tierra de la Agencia Espacial Europea, con el sensor MSI, multiespectral (13 bandas) desde $404 \mathrm{~nm}$ hasta $2200 \mathrm{~nm}$, una resolución espacial de $10 \mathrm{~m}$ y una frecuencia temporal de 5 dias, impensables hasta ahora en imágenes de libre acceso. El estudio se realizó con imágenes de los años 2016 y 2017. Durante este periodo solo se pudieron aprovechar 40 imágenes sin nubes de las 81 que tomó el satélite. Una vez descargadas las imágenes, se utilizó el programa SNAP 5 para su procesado; mediante la herramienta Sen2cor se corrigieron atmosféricamente y con el algoritmo elaborado por Soria et al. 2017 se estimó la [Chl-a] del lago. Los datos estimados se validaron con muestras de campo: se realizaron un total de 18 muestreos y se tomaron 92 muestras en las que se midió la [Chl-a]. Además, para una mejor interpretación de los resultados se tomaron datos de conductividad y profundidad del disco de Secchi en campo y se recopilaron datos hidrológicos, de precipitación y viento. Los resultados de la validación fueron muy buenos puesto que con la correlación lineal entre datos de campo y estimados se obtuvo una $R=0.8$, lo que demuestra la robustez del algoritmo empleado. De la interpretación de los mapas temáticos se pudo extraer que la evolución temporal de la [Chl-a] sigue un patrón bimodal anual, donde la disminución de la [Chl-a] está determinada bien por un aumento notable de la renovación del agua del lago o por una extinción de los nutrientes disponibles debido a un crecimiento excesivo del fitoplancton.

Palabras clave: eutrofización, calidad del agua, gestión hídrica, clorofila-a, teledetección

\section{INTRODUCTION}

When considering ecological water quality, eutrophication is currently the main problem in both inland waters (lakes, reservoirs, etc.) and transition and coastal waters of Europe. And that is the greatest threat to biodiversity (Watt et al., 2007) and to an optimal ecologic state in surface waters (CIS, 2005).

One of the main biological parameters used in water ecology and management is the chlorophyll- $a$, because its concentration in the water provides an approximation on phytoplankton biomass (primary producers). Phytoplankton is the group of organisms responding first to nutrient enrichment, with an excessive growth due to their high rates of replication (e. g. Reynolds, 2006). The increase in phytoplankton reflects symptomatic signs of alteration in both the nutrient cycles and the structure of the trophic network, both related to eutrophication.

In Albufera of València, eutrophication is an old problem given that, following intense eutrophication processes throughout the 1960s, the system shifted from a clear into a turbid stable state which was consolidated by the virtual disappearance of macrophytes in the early 1970s (Vicente \& Miracle, 1992).

Despite all the efforts to reverse the current state of Albufera, the pressure on this system is increasing by the growth of population in its area of influence (waters with a high load of nutrients) and, in addition, the effects of climate change (reduction of precipitation and increase in evaporation). This situation highlights the importance of constant monitoring of this water mass, even though limnological characteristics and its state have been studied in many works. In this sense, remote sensing is an excellent tool for continuous monitoring of the water mass state.

Although remote sensing on freshwater systems has traditionally been limited by the spatial and radiometric resolution of sensors, its use for the study of the properties and processes of freshwater ecosystems has seen an increase in the last years (Hestir et al., 2015). This increase in the use of remote sensing has also been observed in our study area, where in recent years several studies have been carried out with low and high resolution sensors, both spatial and radiometric: Delegido et al., 2014 and Doña et al., 2014 and 2015.

The European Space Agency (ESA) has just deployed a new Earth Observation Satellites, the Sentinel-2 (S2). The mission started in 2015 and is composed of two satellites, called S2A and $\mathrm{S} 2 \mathrm{~B}$, making it an exceptional tool for intensify- 
Table 1. Features of the sensors and satellites used in recent remote sensing studies in Albufera of València. Características de los satelites y sensores utilizados en estudios recientes de teledetección en la Albufera de València.

\begin{tabular}{lccc}
\hline \multicolumn{1}{c}{ Sensor } & $\begin{array}{c}\text { Bandwidth } \\
(\mathbf{n m})\end{array}$ & $\begin{array}{c}\text { Spatial } \\
\text { resolution }(\mathbf{m})\end{array}$ & $\begin{array}{c}\text { Temporal } \\
\text { resolution (days) }\end{array}$ \\
\hline Landsat-TM/ETM+ & $>20$ & $>30$ & 16 \\
MODIS-TERRA & 20 & 500 & 1 \\
Deimos-1 & $>60$ & 22 & 3 \\
CHRIS/PROBA & $5-15$ & $18-36$ & 7 \\
EEI-HICO & 5.7 & 100 & 3 \\
Sentinel-MSI & $>20$ & $>10$ & 5 \\
\hline
\end{tabular}

ing studies on water bodies with a spatial resolution $(10 \mathrm{~m})$ and a temporary frequency (5 days) unthinkable so far in free and open-access imagery. In Table 1 we can see a comparison between this sensor and those used in the last studies carried out in the Albufera of València.

In 2016, the ESAQS project (Ecological Status of Aquatic Systems with Sentinel Satellites) started, aiming to develop and validate algorithms to estimate ecological quality indicators in inland and coastal waters using the new generation of European Earth Observation satellites:
Sentinel-2 and Sentinel-3. The ESAQS project aspires to establish a protocol for regular and frequent monitoring of the ecological status of various reservoirs and lakes in the Valencian region, including the Albufera of València.

In this work we will focus on the study of the temporal and spatial evolution of chlorophyll $a$ concentration [Chl- $a$ ] throughout years 2016 and 2017, in order to show the validity of a proposed algorithm for Sentinel-2 images and an operative method for the multitemporal study in the Albufera of València.
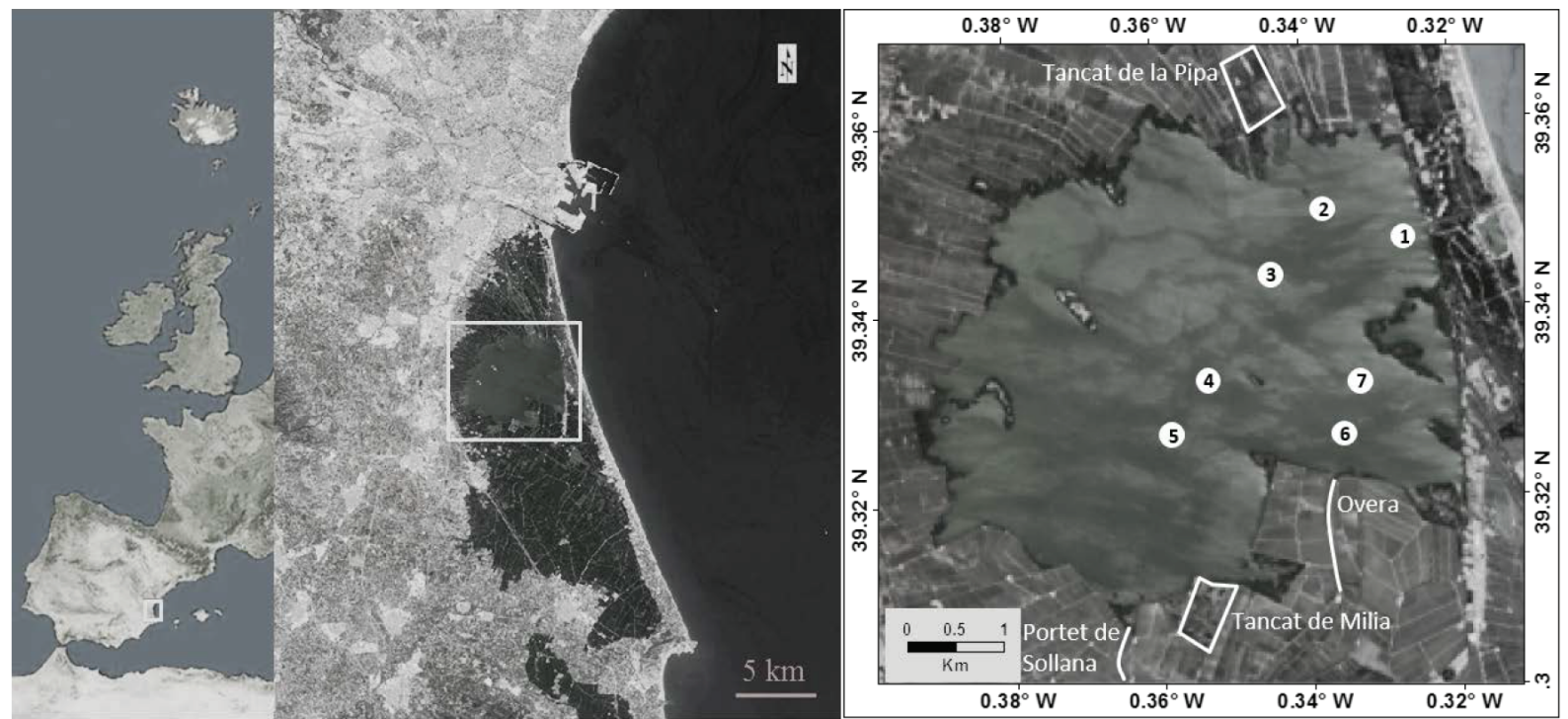

Figure 1. Study site, Albufera of València and sampling locations. Lugar de estudio, Albufera de València y puntos de muestreo. 


\section{MATERIAL AND METHODS}

\section{Study area}

Albufera of València, a Mediterranean oligohaline (1-2 \%o) shallow lake (1-3 m), situated 15 $\mathrm{km}$ south of the city of València (Spain) (Fig. 1) is the largest natural lake of the Iberian Peninsula. It is considered $a$ hypertrophic lake, with average annual chlorophyll a levels of $167 \mu \mathrm{g} / \mathrm{L}(4-322$ $\mu \mathrm{g} / \mathrm{L})$, Secchi disk depth of $0.34 \mathrm{~m}(0.18-1.0 \mathrm{~m})$, total phosphorus of $155 \mu \mathrm{g} / \mathrm{L}(41-247 \mu \mathrm{g} / \mathrm{L})$ and total nitrogen of $3.9 \mathrm{mg} / \mathrm{L}(1.8-6.6 \mathrm{mg} / \mathrm{L})$ (Onandia et al., 2015).

Albufera of València hydrology is regulated by the local water council to meet the needs of surrounding agricultural lands, mainly rice paddies. Its outflow to the Mediterranean Sea is controlled by sluicegates located on outlet canals. From November to the beginning of January, the sluicegates are closed, the unsown rice fields remain flooded (the local term for it is Perellona$d a$ ) and the water level of the lagoon is about 20-30 cm above normal. During January and
February, there is a period of higher water renewal; flooded rice fields are emptied, water flows out to the sea through the opened sluicegates for that purpose and the level of the lagoon drops. Rice fields remain dry until the beginning of May when they are flooded again for cultivation. During rice planting, the sluicegates are partially closed to maintain a mean water flow and a mean water level (Miracle \& Sahuquillo, 2002).

\section{Remote sensing images. Sentinel-2}

The ESA S2 mission is a two satellite constellation: S2A (launch date: June 23, 2015) and S2B (launch date: March 7, 2017). Each satellite has a sensor, the MSI, which measures the Earth's reflected radiance in 13 spectral bands from visible to VNIR and SWIR, with a spatial resolution of 10, 20 and $60 \mathrm{~m}$ (ESA, 2012). Table 2 shows the most relevant information about the MSI bands and her spatial resolution.

With its 13 spectral bands, $290 \mathrm{~km}$ swath width and high revisit frequency (5 days revisit at the Equator), Sentinel-2 supports a wide range

Table 2. Spectral information and spatial resolution of Sentinel-2 A and B for each band (ESA, 2012). Información espectral y resolución espacial de las bandas de Sentinel-2 A y B (ESA, 2012).

\begin{tabular}{cccccc}
\hline & \multicolumn{2}{c}{ S2A } & \multicolumn{2}{c}{ S2B } & \\
\hline $\begin{array}{c}\text { Band } \\
\text { Number }\end{array}$ & $\begin{array}{c}\text { Central } \\
\text { wavelength } \\
(\mathbf{n m})\end{array}$ & $\begin{array}{c}\text { Bandwidth } \\
(\mathbf{n m})\end{array}$ & $\begin{array}{c}\text { Central } \\
\text { wavelength } \\
(\mathbf{n m})\end{array}$ & $\begin{array}{c}\text { Bandwidth } \\
(\mathbf{n m})\end{array}$ & $\begin{array}{c}\text { Spatial } \\
\text { resolution } \\
(\mathbf{m})\end{array}$ \\
\hline $\mathbf{1}$ & 443.9 & 27 & 442.3 & 45 & 60 \\
$\mathbf{2}$ & 496.6 & 98 & 492.1 & 98 & 10 \\
$\mathbf{3}$ & 560.0 & 45 & 559 & 46 & 10 \\
$\mathbf{4}$ & 664.5 & 38 & 665 & 39 & 10 \\
$\mathbf{5}$ & 703.9 & 19 & 703.8 & 20 & 20 \\
$\mathbf{6}$ & 740.2 & 18 & 739.1 & 18 & 20 \\
$\mathbf{7}$ & 782.5 & 28 & 779.7 & 28 & 20 \\
$\mathbf{8}$ & 835.1 & 145 & 833 & 133 & 10 \\
$\mathbf{8 a}$ & 864.8 & 33 & 864 & 32 & 20 \\
$\mathbf{9}$ & 945.0 & 26 & 943.2 & 27 & 60 \\
$\mathbf{1 0}$ & 1373.5 & 75 & 1376.9 & 76 & 60 \\
$\mathbf{1 1}$ & 1613.7 & 143 & 1610.4 & 141 & 20 \\
$\mathbf{1 2}$ & 2202.4 & 242 & 2185.7 & 238 & 20 \\
\hline
\end{tabular}


of land studies and programs, and reduces the time required to build an European cloud-free image archive (ESA, 2012). The mission was initially optimized for studies on vegetation, urban planning and terrestrial ecosystems, but the inclusion of new bands in the red-edge (the limit of red and infrared spectral regions), its radiometric quality and its high spatial resolution, has proven its usefulness for the study of inland waters (Soria et al., 2017).

Images used in this study were downloaded from the ESA archives and the dataset consists of Sentinel 2 A and B imagery. Software SNAP version 5 (Brockmann Consult) was used for image processing. All images were downloaded in L1C product in order to use the same atmospheric correction for all of them, by means of the Sen2Cor processor. This processor was designed for vegetation and land, but provides good results in eutrophic waters (Soria et al., 2017; Ruescas et al., 2016).

As the algorithm used in the analysis -described below- uses bands of different spatial resolution, the images have previously been resampled at $20 \mathrm{~m}$ with SNAP interpolation tools.

\section{Methods}

Throughout 2016-2017 Sentinel 2 was able to take 81 images in our study area ( 62 by S2A and 19 by S2B), but cloud coverage has only allowed to use 40 remote sensing images to observe the spatial and temporal variation of [Chl- $a]$ along this period. The time window between image acquisition and field campaigns was extended to 3 days following the methodology of Kutser (2012). We used 17 images that were close to campaign data: 7 were coincident, 3 with one day difference, 5 with two days difference and only 2 with three days difference.

The algorithm used for estimated [Chl- $a]$ from S2 images to obtain thematic maps is an adaptation of TBDO, triband model of Dall'Olmo et al. (2003), developed for the Albufera of València in Soria et al. (2017) and Pereira-Sandoval et al. (2018):

$$
T B D O=R(740) \times\left(\frac{1}{R(665)}-\frac{1}{R(705)}\right)
$$

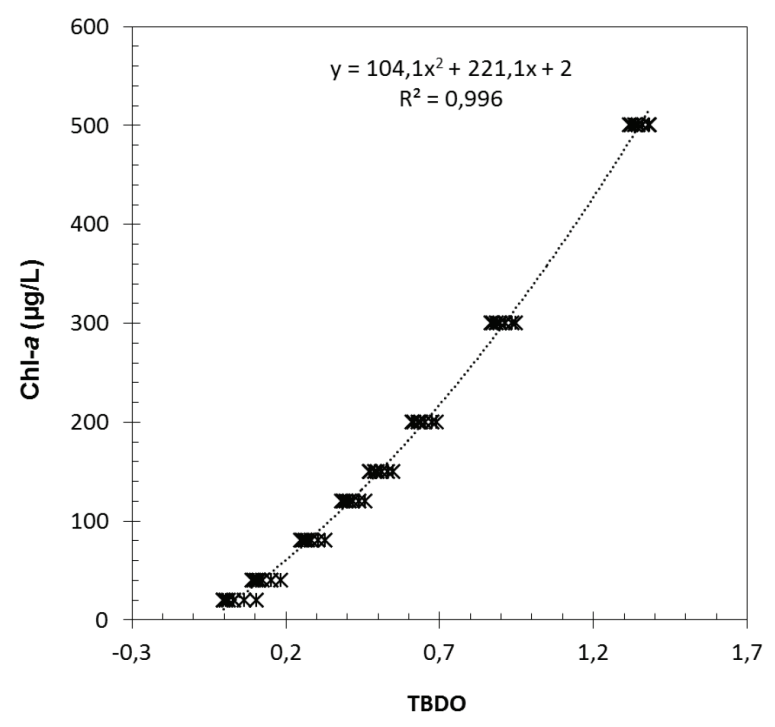

Figure 2. Triband model, TBDO, calibration (Soria et al., 2017; Pereira-Sandoval et al., 2018). Calibración del modelo tribanda, TBDO (Soria et al., 2017; Pereira-Sandoval et al., 2018).

Figure 2 shows the relationship between $[\mathrm{Chl}-a]$ and triband model $\left(\mathrm{R}^{2}=0.996\right)$ and the corresponding algorithm, a second degree polynomial fit intuited from the data structure and avoiding negative predictions of the model due to low chlorophyll values, which would occur with a simpler lineal fit. This calibration was performed with a simulated $\mathrm{S} 2$ reflectivity base with a radiative transfer model, Hydrolight (HE5), for a range of [Chl- $a$ ] between 20 and $500 \mu \mathrm{g} / \mathrm{L}$.

In summary, the equation applied on the S2 images to obtain $[\mathrm{Chl}-a]$ was:

$$
[\mathrm{Chl}-a](\mu \mathrm{g} / \mathrm{L})=104.1 \mathrm{TBDO}^{2}+221.1 \mathrm{TBDO}+2
$$

TBDO index has previously been obtained using equation (1).

\section{Field campaigns}

To validate the estimated data, water samples were collected at seven different points within the lake (Fig. 1), but we did not always take all the points. From January 2016 to November 2017, a total of 18 field campaigns were completed and 92 georeferenced samples were collected. 
Conductivity and Secchi disk depth were measured in situ, and [Chl-a] was measured in laboratory using a spectrophotometer. Samples were filtered through $0.4-0.6 \mu \mathrm{m} \mathrm{GF} / \mathrm{F}$ glass fiber filters, extracted according to standard methods (Shoaf \& Lium, 1976) and data was obtained using the calculation methods by Jeffrey \& Humphrey (1975). Meteorological information was provided by the Tancat de la Pipa weather station, situated close to the northern lake shore.

\section{Statistical analyses}

To peruse [Chl-a] data of the thematic maps presented in this work, obtained by applying equation (2) to S2 images, a boxplot with data on the entire surface of the lake for each image was created. This enables us to see the data dispersion on each one of them, and observe variations depending on the levels of $[\mathrm{Chl}-a]$ in the lake.

For the comparison between estimated data and field data, its adjustment to a linear regression was checked and the root-mean-square error (RMSE) and percentage of mean absolute error (MAE) were calculated. Additionally, to see whether differences between the values provided by the different monitoring points were statistically significant the Student t-test was applied.

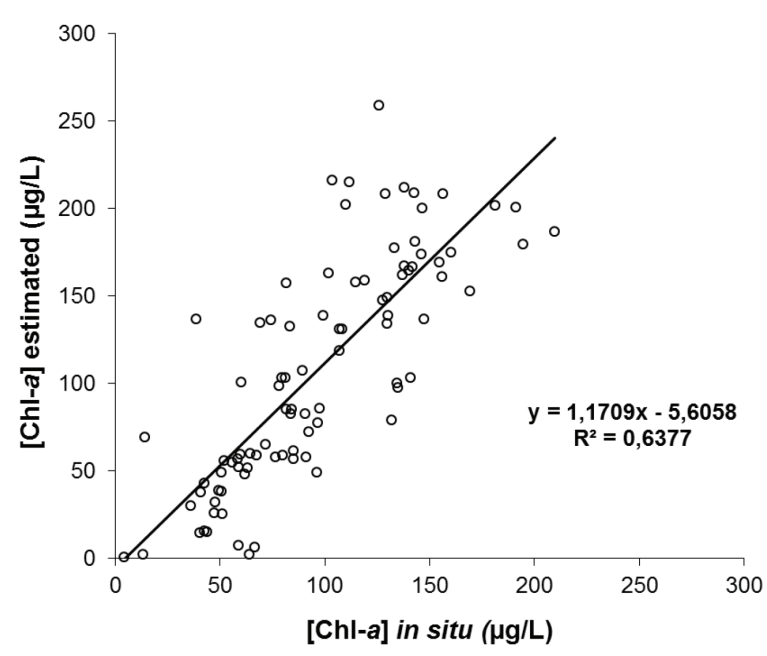

Figure 3. Algorithm validation with field data. Validación del algoritmo con datos de campo.

\section{RESULTS}

\section{Field data}

During the two years of study, a total of 92 samples were collected on 18 different dates. From these samples we will show the mean, the maximum value and the minimum value for each of the measured variables.

The average of the results of [Chl- $a$ ] was 97 $\mu \mathrm{g} / \mathrm{L}$, ranging between $209 \mu \mathrm{g} / \mathrm{L}$ registered at the sampling point 2 (North) during October 2017, and the $4.5 \mu \mathrm{g} / \mathrm{L}$ registered at the sampling point 6 (South) during April 2017. These values show the great spatial and temporal variability occurring within the lake. To a lesser extent, the Secchi disk depth data also shows this variability, with the maximum value of $0.62 \mathrm{~m}$ recorded in April 2017 in the South and the minimum value of 0.2 $\mathrm{m}$ observed in sampling points 4 and 5 in January 2016; the average was $0.3 \mathrm{~m}$. Regarding conductivity, the mean during the two years of sampling was $2137 \mu \mathrm{S} / \mathrm{cm}$, with a maximum value of 3120 $\mu \mathrm{S} / \mathrm{cm}$ registered at point 1 (East) in September 2017, whereas the minimum value was at sampling point 7 in January 2017.

\section{Algorithm validation}

In order to validate the applied algorithm (equation 2), the linear regression method was used with the field data and values estimated by the algorithm from the S2 images (Fig. 3). We obtain an $\mathrm{R}$ of 0.80 for a total of 92 samples, which places us at a degree of significance lower than 0.001 . In addition, the slope value is very close to 1 , with an intercept value close to 0 considering that we work with values between 4 and 200 $\mu \mathrm{g} / \mathrm{L}$, thus ratifying the high predictive capacity of the algorithm used.

Regarding the calculated errors, the RMSE reached a value of $40 \mu \mathrm{g} / \mathrm{L}$ and the percentage of MAE was $9.6 \%$.

\section{Image output}

By applying equation 2 to S2 images we obtain maps of $[\mathrm{Chl}-a]$ that allow us to observe its temporal and spatial evolution. Out of 40 images 

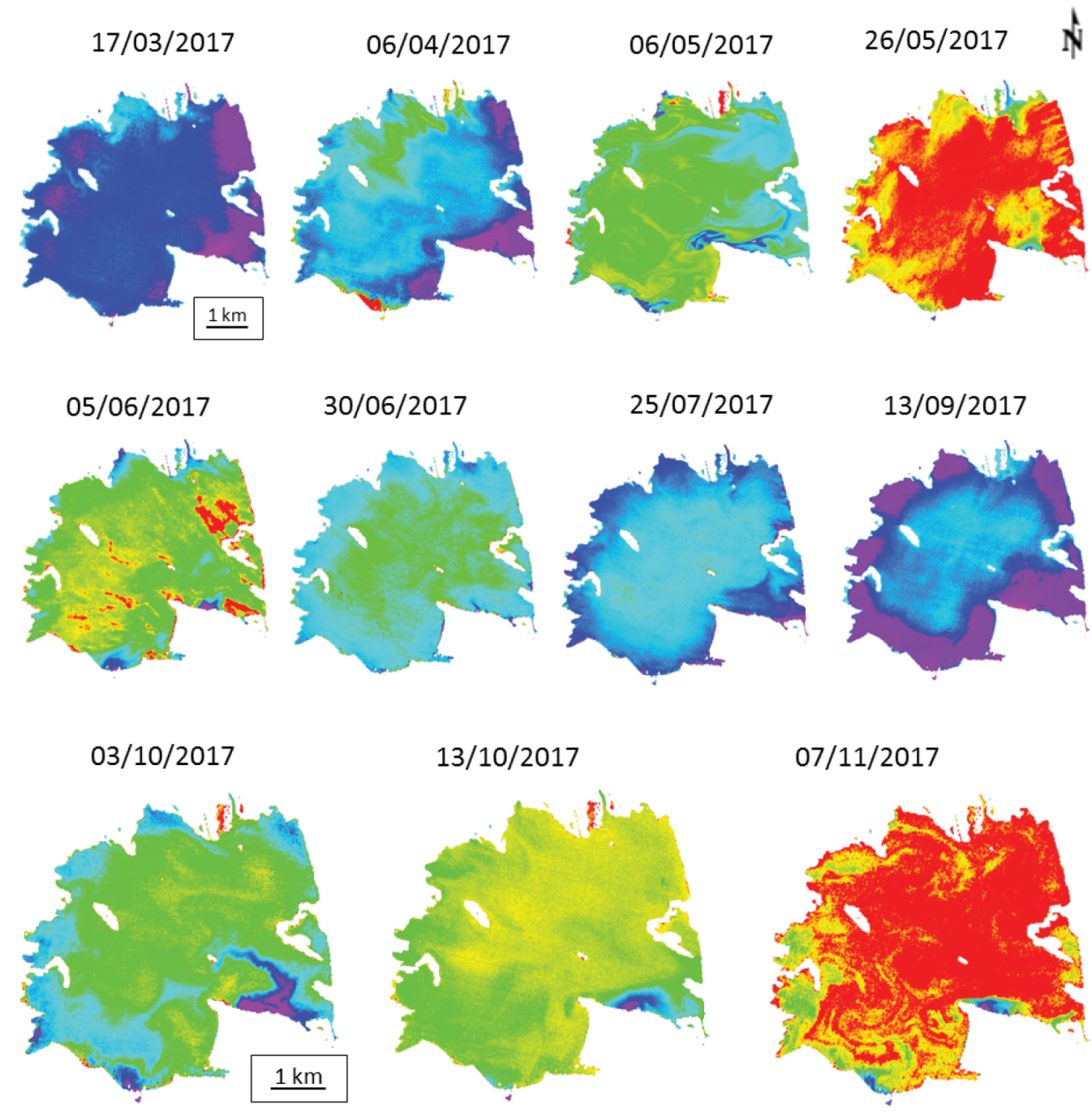

$07 / 11 / 2017$

$12 / 11 / 2017$

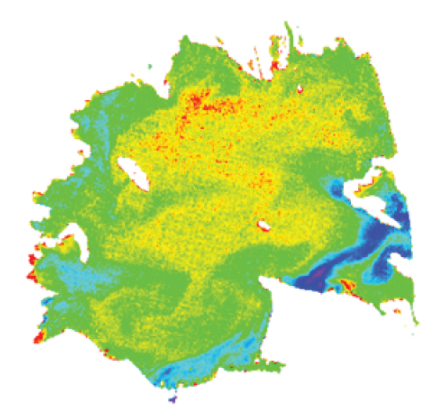

$17 / 11 / 2017$

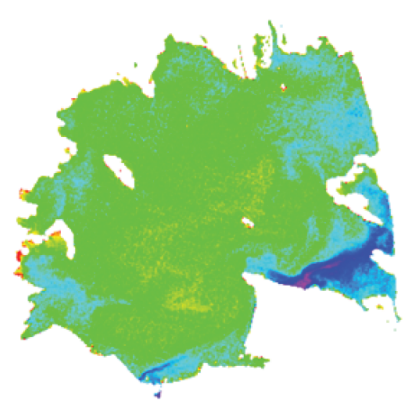



$22 / 11 / 2017$

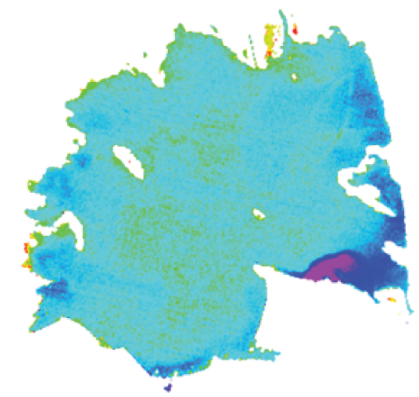

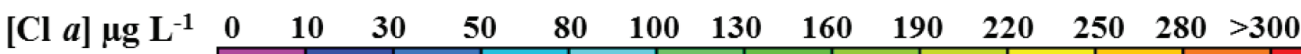

Figure 4. Temporal evolution of [Chl-a] in Albufera of València for the year 2017. Evolución temporal de la [Chl-a] en la Albufera para el año 2017. 
processed for this work, in Figure 4 we present only 14 , those that clearly illustrate changes in [Chl-a]. The sequence of images selected shows the annual cycle of [Chl- $a$ ] throughout 2017. Images in the first row show the increase of [Chl- $a$ ], from the low concentrations in March to those highest in late May - it begins in the north, then expands to the south and finally spreads to the east. In the following months, [Chl-a] decreases progressively from the shore towards the center of the lake until reaching the lowest values at the end of summer. In the third row, an increase of [Chl- $a$ ] is observed from the center of the lake towards the shore, until reaching a maximum of [Chl-a] in November, the autumn maximum. Ultimately, in the last three images of the sequence, we observe how [Chl- $a]$ decreases from the coast towards the center of the lake. Throughout this sequence it is evident that the values of $[\mathrm{Chl}-a]$ around sampling point 6 (South) are consistently much lower than those in the rest of the lake, due to the water intake going through the sèquia of Overa (a man-made irrigation canal) - this is true throughout the year except in the summer months.

The [Chl- $a$ ] data on the entire surface of the lake of the thematic maps are summarized graphically in Figure 5, where it is observed that data dispersion is directly proportional to the median, that is to say, when lake concentration is greater the data dispersion is at its highest. In this graph also we can clearly see the bimodal behavior of $[$ Chl- $a]$ throughout the year.

\section{$[$ Chl- $a]$ in situ vs. [Chl- $a]$ estimated}

In addition to the linear regression, to reinforce the good connection between the field data and the estimated data, the temporary evolution of [Chl-a] (in situ and estimated) has been represented in Figure 6 for the two years of study. For the field data we have used the mean chlorophyll values for each sampling and for the estimated data the mean of the points corresponding to the sampling sites nearest the sampling day (Fig. 6 A). As we can observe, both field and estimated data describe the same variation pattern of [Chl-a] over the two years.

In Figure 6, we also plot the values of [Chl-a] in field and estimated data for the points located at the North (Fig. 6 B) and South (Fig. 6 C) of the lake. Those points registered the maximum and minimum values respectively, and the difference between its [Chl- $a$ ] values have proven to be statistically significant $(\mathrm{t}=2.202 ; p=0.035)$ according to the Student t-test. Such difference was also significant between point 6 (South) and point 1 (East): $\mathrm{t}=-2.429 ; p=0.021$. That exemplifies the differences between the northeastern and southern parts of the lake. Thus, in Figure 6 we can also observe how the algorithm responds appropriately for high and low [Chl-a].

\section{Chlorophyll evolution}

In order to be able to represent [Chl- $a$ ] evolution with greater precision, the means for all the

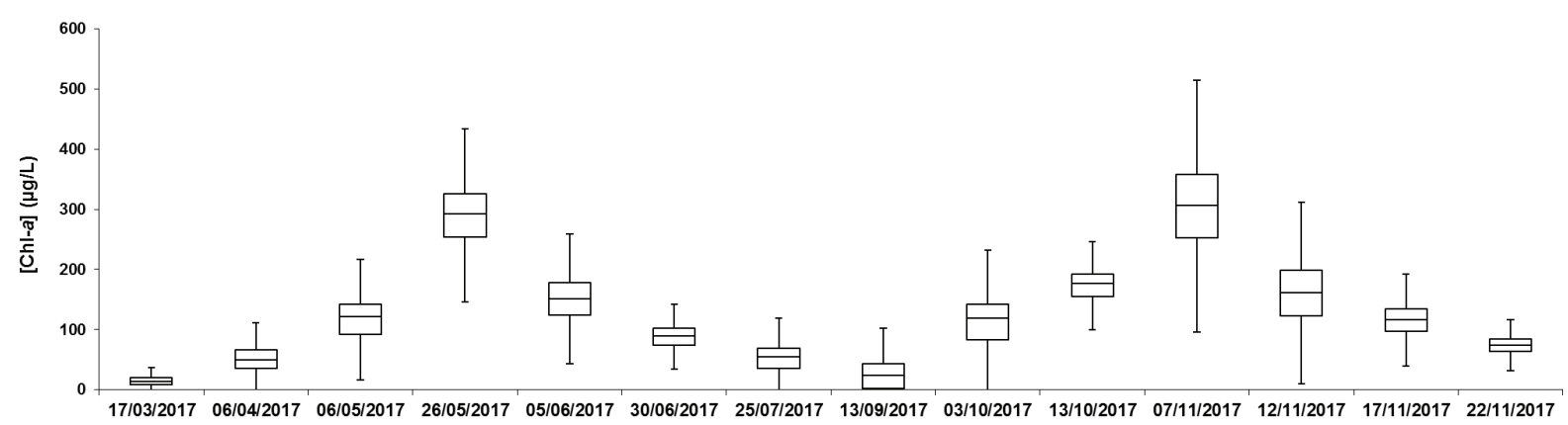

Figure 5. Boxplot of the values range estimated for the images shown in figure 4. For each image, the box bounds the interquartile range (IQR; 25-75 percentile), the horizontal line inside the box indicates the median, and whiskers are 1.5*IQR. Gráfico de cajas del rango de valores estimado para cada imagen mostrada en la figura 4. Para cada imagen, la caja limita el rango intercuartil (IQR; percentil 25-75), la línea horizontal dentro de la caja indica la mediana y los bigotes son el $1.5 * I Q R$.

Limnetica, 38(1): 457-469 (2019) 

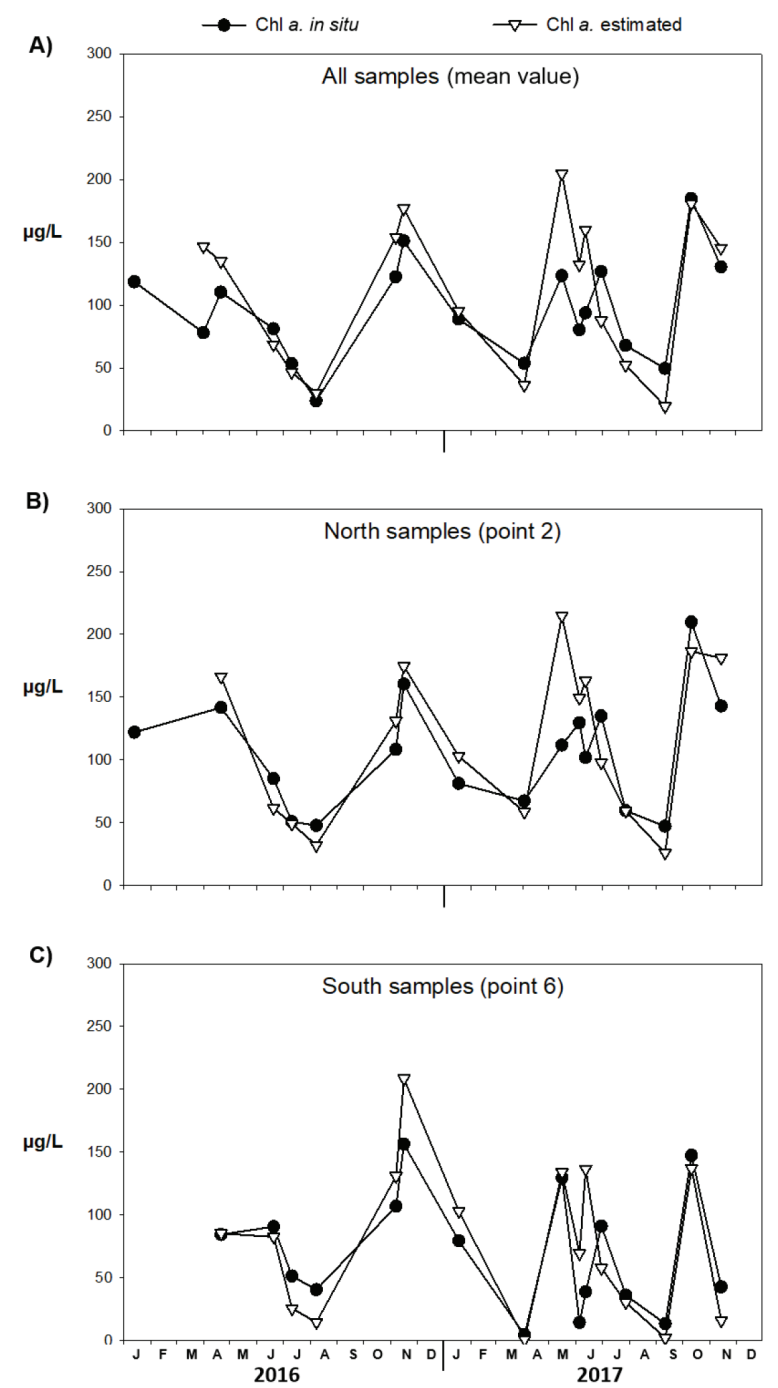

Figure 6. Comparison between in situ and estimated [Chl- $a$ ] using on the one hand the mean of all samples (A) and on the other hand the values of North (B) and South (C) sampling points separately. Comparativa entre la [Chl-a] in situ y estimada utilizando por un lado la media de todas las muestras (A) y por otro lado los valores de los puntos de muestreo Norte (B) y Sur (C) por separado.

[Chl- $a]$ values on the lake surface were calculated for each one of the 40 processed images. This evolution is represented in Figure 7 along with the conductivity and Secchi disk depths of the field values, and meteorological information on precipitation. [Chl-a] evolution (Fig. 7A) over the two years registers two minima and two maxima, very marked annual peaks - minima are registered one in March (beginning of spring), the other at the end of August and the beginning of September (end of summer); peaks are seen in May (end of spring) and November (end of autumn). Looking closely at the two minima, we can see at graph $\mathrm{C}$ that they coincide with moments of greatest water renewal (if we exclude the winter period).

Regarding conductivity (Fig. 7B), it stays above $1500 \mu \mathrm{S} / \mathrm{cm}$ throughout the year, with maximum values recorded during the summer months. At the beginning of 2017 there is a decrease in conductivity, coinciding with a period of heavy rains occurred at the end of 2016 and the beginning of 2017 (Fig. 7C), happening at the time of greatest water renewal of the lake.

In the Secchi disk depths evolution for 2017 (Fig. 7D), the two peaks with greater transparency coincide with the moments of minor [Chl-a], however, in 2016 there are no major variations.

\section{DISCUSSION}

Regarding the algorithm used to estimate the [Chl-a] values from S2 images, even though the RMSE calculated with the data in our study is much higher than that calculated by Soria et al. (2017) of only $15.7 \mu \mathrm{g} / \mathrm{L}$, the good coefficient of correlation between the field and estimated data, the low percentage of MAE (9.6\%) and the correspondence in the temporary variation between in situ and estimated data show that the algorithm used delivers very good matching results for the water body studied. Therefore, this algorithm would not require major optimization to carry out accurate estimates of $[\mathrm{Chl}-a]$ in Albufera of València, a very variable water body as regards to [Chl- $a$ ].

If we look at the thematic maps obtained (Fig. 4 ), the annual evolution of the [Chl- $a$ ] registers two minima and two very conspicuous maxima. This depends greatly on the sampling scheme but a bimodal pattern arises and this is thought to be caused by an assortment of natural and human factors. In the description of the study site we have mentioned that in Albufera of València water system management, human hand plays a determinative role.

The first $[\mathrm{Chl}-a]$ minimum is recorded around March coinciding with an increase in the lake's 
A)

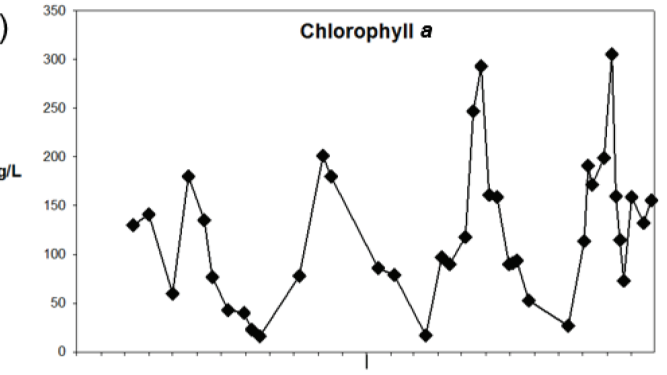

B)

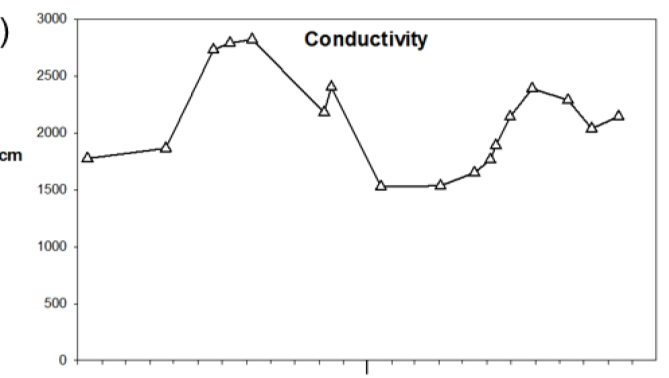

C)

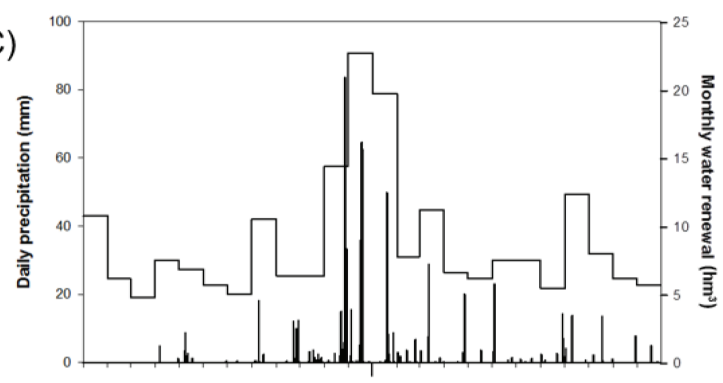

D)

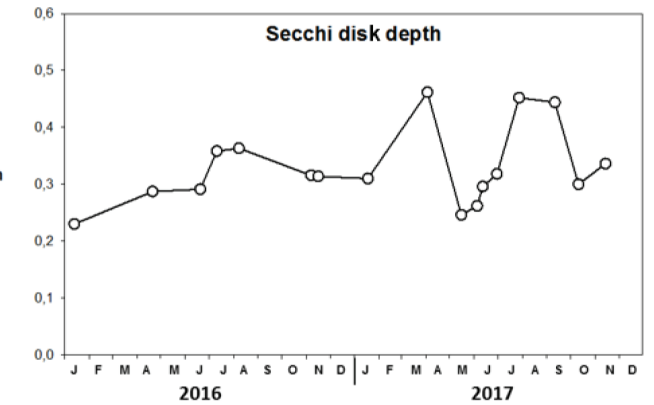

Figure 7. Evolution of $[\mathrm{Chl}-a]$ using the mean values on the entire water surface from estimated values (A), the mean of the field data for conductivity (B) and Secchi disk depth (D), hydrological information for water renewal (C-coninuous line) and meteorological information for precipitation data (C-bars). Evolución de la [Chl-a] utilizando los datos estimados para toda la superficie de agua (A), la media de los datos de campo para la conductividad (B) y la profundidad del disco de Secchi (D), información hidrológica para la renovación del agua (C-línea continua) e información meteorológica para los datos de precipitación (C-barras). water renewal due to water coming from the rice paddies that have been purposefully flooded in winter. After some weeks, the [Chl- $a]$ increases remarkably until the first annual maximum that occurs at the end of May. Then there is a sharp decline in the summer period that evidences a decline in primary production motivated by nutrient depletion after the typical production peak in late spring (Russel-Hunter, 1970). This second decline in [Chl- $a$ ] due to nutrient depletion, is facilitated by an increase in the renewal of the lake's water caused by the draining of the rice paddies previous to the crop harvest period. Lastly, in November, the second yearly maximum of [Chl- $a$ ] occurs, caused by nutrients entering the system along with the water coming from crop fields. Once nutrients are depleted, [Chl-a] stabilizes through the winter.

Temporal sequence variations are not the only information gleaned, the images also highlight the spatial variation of $[\mathrm{Chl}-a]$. The differences in the increase of [Chl- $a]$ in the spring with respect to the increase in autumn after the two annual minima could be explained by the factors causing the decrease of the [Chl- $a$ ]. In March the decrease is due to a strong renovation of the lake's water by the draining of the flooded fields, the water within the lake is shifted to the sea, hence the increase of $[$ Chl- $a]$ would follow that same trend. However, at the end of the summer the renovation is not of such magnitude and the decrease of $[\mathrm{Chl}-a]$ is due to the depletion of nutrients, depleted first in the areas where there is a smaller volume of water, that is, by the lake shore, and then spreading towards the center of the lake, so the increase of [Chl- $a$ ] would follow the opposite route.

Within this spatial heterogeneity, thanks to variations in [Chl- $a]$, we can indentify areas of worse or better quality water. We would like to note an important entry point of better quality water at the mouth of the Overa irrigation canal, just south where sampling point 6 is located. Thanks to $\mathrm{S} 2$ images the water inflow can be observed as well as the behavior of the plume that forms within the lake - that would not be possible highlight with current field sampling techniques. If we follow the dynamics of this better quality water plume, it generally travels eastwards to the watercourses linking the lake with the sea, except 
when winds at speeds above $20 \mathrm{~km} / \mathrm{h}$ cause that plume to shift in other directions. Current situation indicates that, in general, water entering through Overa only renews the southeastern sector of the lake with an 11-day renovation period (Soria \& Vicente, 2002), but this water could make a greater contribution to the lake renovation if we would move the entry point to the southwest as much as possible, thus impacting a sector that has a 53-day renovation period (Soria \& Vicente, 2002). Taking into account the connection between irrigation canals, water coming from Overa could be diverted through Campets irrigation canal and then through Portet de Sollana canal so that it finally enters into the southwest part of the lake, near to the Tancat de Milia, a green filter created to minimize the nutrients in the treated water coming out of the Albufera-Sud plant.

If we compare the evolution of the parameters considered with respect to previous studies, the Secchi disk depth values and conductivity are similar to those in earlier studies such as those presented in Soria et al. (1987). On the other hand, [Chl- $a$ ], despite having fluctuations similar to the 1998-2006 period studied in Romo et al. (2008), now presents greater amplitudes because decreases of [Chl- $a$ ] reach lower values, indicating a tendency towards an improvement in the ecological status of the lake.

\section{CONCLUSIONS}

In summary, this study shows that the algorithm to estimate the [Chl- $a$ ] from S2 images is consistent and suitable for use within a protocol whose main purpose aims to monitor Albufera of València's ecological status.

Arguably, the results obtained are dependent on the sample scheme, but an annual bimodal tendency is deduced from the monitoring carried out throughout the period. The decrease of [Chl- $a$ ] is determined either by a marked increase in the water renewal of the lake or by the depletion of nutrients. As a continuous contribution of quality water seems increasingly unlikely and utopic, we suggest focusing on improving water quality currently entering into the system so as to diminish the peaks of spring and autumn. In this sense, we think certain actions would reduce nutrient inputs and improve water renovation. Such actions might be (1) starting the tertiary treatment in sewage treatment plants draining into the canals leading to the lake, (2) making the green filter at Tancat de Milia effective, (3) encouraging organic farming inside the Albufera of València Natural Park and (4) the efficient management of water contributions to promote the renewal of, especially, the western part of the lake.

\section{ACKNOWLEDGEMENTS}

We thank the Tancat de la Pipa for providing daily data of precipitation and wind, and the Jucar Basin Authority for hydrological data. This work has been supported by the project GVPROMETEO2016-132 from Generalitat Valenciana.

\section{REFERENCES}

CIS. 2005. Towards a guidance document on eutrophication assessment in the context of European water policies. Common Implementation Strategy for the Water Framework Directive (2000/60/EC) (Provisional document). European Commission.

DALL'OLMO, G., A. GITELSON \& D. RUNDQUIST. 2003. Towards a unified approach for remote estimation of chlorophyll-a in both terrestrial vegetation and turbid productive waters. Geophysical Research Letters, 30(18). DOI: 10.1029/2003GL018065

DELEGIDO, J., C. TENJO, A. RUIZ-VERDÚ, R. PEÑA \& J. MORENO. 2014. Modelo empírico para la determinación de clorofila- $a$ en aguas continentales a partir de los futuros Sentinel-2 y 3. Validación con imágenes HICO. Teledetección, 41: 37-47.

DOÑA, C., J. M. SANCHEZ, V. CASELLES, J. A. DOMÍNGUEZ \& A. CAMACHO. 2014. Empirical relationships for monitoring water quality of lakes and reservoirs through multispectral images. IEEE Journal of Selected Topics in Applied Earth Observations and Remote Sensing, 7: 1632-1641. DOI: 10.1109/ JSTARS.2014.2301295

DOÑA, C., N. B. CHANG, V. CASELLES, J. M. SÁNCHEZ, A. CAMACHO, J. DELEGI- 
DO \& B. W. VANNAH. 2015. Integrated satellite data fusion and mining for monitoring lake water quality status of the Albufera de Valencia in Spain. Journal of environmental management, 151: 416-426. DOI: 10.1016/j.jenvman.2014.12.003

ESA. 2012. Sentinel-2: ESA's Optical High-Resolution Mission for GMES Operational Services. K. Fletcher (ed.). ESA Communications. Noordwijk, The Netherlands. DOI: 10.1016/j.rse.2011.11.026

JEFFREY, S. T. \& G. F. HUMPHREY. 1975. New spectrophotometric equations for determining chlorophylls a, b, c1 and c2 in higher plants, algae and natural phytoplankton. Biochemie und Physiologie der Pflanzen, 167: 191-194. DOI: 10.1016/S0015-3796(17)30778-3

HESTIR, E. L., V. E. BRANDO, M. BRESCIANI, C. GIARDINO, E. MATTA, P. VILLA \& A. G. DEKKER. 2015. Measuring freshwater aquatic ecosystems: The need for a hyperspectral global mapping satellite mission. Remote Sensing of Environment, 167: 181-195. DOI: 10.1016/j.rse.2015.05.023

KUTSER, T. 2012. The possibility of using the Landsat image archive for monitoring long time trends in coloured dissolved organic matter concentration in lake waters. Remote Sensing of Environment, 123: 334-338. DOI: 10.1016/j.rse.2012.04.004

MIRACLE, M. R. \& M. SAHUQUILLO. 2002. Changes of life-history traits and size in Daphnia magna during a clear-water phase in a hypertrophic lagoon (Albufera of Valencia, Spain). Verhandlungen des Internationalen Verein Limnologie, 28: 1203-1208.

ONANDIA, G., A. GUDIMOV, M. R. MIRACLE, \& G. ARHONDITSIS. 2015. Towards the development of a biogeochemical model for addressing the eutrophication problems in the shallow hypertrophic lagoon of Albufera de Valencia, Spain. Ecological Informatics, 26: 70-89. DOI: 10.1016/j.ecoinf.2015.01.004 PEREIRA-SANDOVAL, M., A. RUIZ-VERDÚ, C. TENJO, J. DELEGIDO, E. P. URREGO, R. PEÑA, E. VICENTE, J. M. SORIA, X. SORIA-PERPINYÀ \& J. MORENO. 2018. Calibration and validation of algorithms for the estimation of chlorophyll-a and Secchi disc depth in inland waters with Sentinel-2. Send to Limnetica - Special Issue A Tribute to Maria Rosa Miracle.

ROMO, S., A. GARCÍA-MURCIA, M. J. VILLENA, V. SÁNCHEZ \& A. BALLESTER. 2008. Tendencias del fitoplancton en el lago de la Albufera de Valencia e implicaciones para su ecología, gestión y recuperación. Limnetica, 27: 011-28.

RUESCAS, A. B., M. PEREIRA-SANDOVAL, C. TENJO, A. RUIZ-VERDÚ, F. STEINMETZ \& L. DE KEUKELAERE. 2016. Sentinel-2 Atmospheric Correction Intercomparison over two lakes in Spain and Peru-Bolivia. CLEO. ESA-ESRIN. Frascati, Rome, Italy. 6-8 September 2016.

REYNOLDS, C. S. 2006. Ecology of Phytoplankton (Ecology, Biodiversity and Conservation). Cambridge University Press. Cambridge, UK.

RUSSEL-HUNTER, W. 1970. Aquatic productivity: An Introduction to some Basic Concepts of Biological Oceanography and Limnology. Mc Millan, NY, USA.

SHOAF, W. T. \& B. W. LIUM. 1976. Improved extraction of chlorophyll $a$ and $b$ from algae using dimethyl sulphoxide. Limnology and Oceanography, 21: 926-928. DOI: 10.4319/lo.1976.21.6.0926

SORIA, J. M., M. R. MIRACLE \& E. VICENTE. 1987. Aporte de nutrientes y eutrofización de la Albufera de Valencia. Limnetica, 3(2): 227-242.

SORIA, J. M., \& E. VICENTE. 2002. Estudio de los aportes hídricos al parque natural de la Albufera de Valencia. Limnetica, 21(1-2): 105-115.

SORIA, X., J. DELEGIDO, E. P. URREGO, M. PEREIRA-SANDOVAL, E. VICENTE, A. RUIZ-VERDÚ, J. M. SORIA, R. PEÑA, C. TENJO, J. MORENO. 2017. Validación de algoritmos para la estimación de la clorofila- $a$ con Sentinel-2 en la Albufera de València. Proceedings of the XVII Congreso de la Asociación Española de Teledetección. Octubre 3-7, 2017. Murcia, Spain: 289-292.

VICENTE, E. \& M. R. MIRACLE. 1992. The coastal lagoon Albufera de Valencia: An ecosystem under stress. Limnetica, 8: 87-100. WATT, A.D., R.H.W. BRADSHAW, J. YOUNG, 
D. ALARD, T. BOLGER, D. CHAMBERLAIN, F. FERNÁNDEZ-GONZÁLEZ, R. FULLER, P. GURREA, K. HENLE, R. JOHNSON, Z. KORSÓS, P. LAVELLE, J. NIEMELÄ, P. NOWICKI, M. REBANE, C. SCHEIDEGGER, J. P. SOUSA, C. VAN
SWAAY \& A VANBERGEN. 2007. Trends in biodiversity in Europe and the impact of land-use change. In: Biodiversity under Threat. Hester, R.E., \& R.M. Harrison, (Eds.): 135-160. Royal Society of Chemistry, Cambridge, UK.

Con el apoyo de:
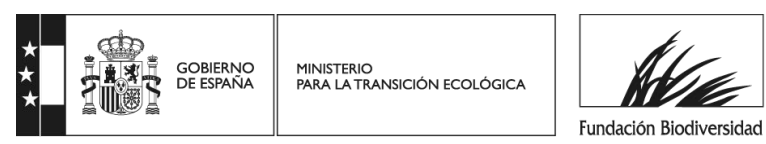